\title{
Village Normativities and the Portuguese Imperial Order: The Case of Early Modern Goa
}

\author{
Ângela Barreto Xavier
}

\section{Introduction}

Upon visiting the villages of the 'Old Conquests' of Goa today-the territories that included Tiswadi, Salcete, and Bardez - it would be clear that they are very different from those of Portugal. Dominated by the Portuguese for 450 years, one could conceivably expect more similarities. Their 'Indianness', particularly in what concerns their religious normativity, was reconstructed during the 19th and 2 oth centuries. However, before the 19th century, the 'Lusitanization' of these villages - that is to say, the incorporation of Portuguese-style practices into village life-was more explicit in very specific dimensions, namely the administrative, legal, and religious ones. This chapter addresses some of the dimensions of this process from the perspective of the life and afterlife of a Portuguese imperial document of $15^{26}$, the Foral dos usos e costumes dos Gancares e Lavradores da Ilha de Goa e outras annexas a ella, better known as Foral de Mexia, henceforth referred to as Foral. ${ }^{1}$

Since the 16 th century, Portuguese imperial administrators and, later, scholars have collected a large body of knowledge about Goan normative orders and their cultural differences in relation to the Portuguese normative orders they were familiar with (which included their African dominions). Following this, European travelers, missionaries, and merchants have also registered information about the rules that operated in different parts of Western India, particularly those relating to religion, marriage, hereditary offices, and land. The relationship between these normativities and the Portuguese imperial order, however, still needs further study.

Normativities, as defined by Thomas Duve, are the sets of juridical, religious, social, and economic norms which guide individuals, groups, and peoples in

1 There are several published versions of this. In this text, I use the version provided by Cunha Rivara in the Fasc. 5, vol. 1 of Archivo Portuguez Oriental (henceforth APo), referred to in the footnotes as Foral dos usos e costumes. 
their relationships with others and the world. ${ }^{2}$ This chapter focuses on normativities related to the political, administrative, and judicial order of the Goan villages, while acknowledging that their delimitation—nowadays explicit—is difficult to define given the overlaps between those normativities and other spheres of power, like the religious one, for example.

Scholars have argued that many of the political, administrative, and judicial institutions found by the Portuguese in the territories they conquered not only survived imperial conquest, but were also crucial to constructing the imperial order. For these authors the case of Goa was paramount. ${ }^{3}$ Seized in 1510 from the Sultanate of Bijapur, the preservation of many of the institutions belonging to the previous Muslim dominion was evident. Similarly, the primary forms of administration in the Goan villages - namely the gaunkaris (an agrarian association dominated by specific lineages and their members) and the gaunkars, that controlled the lands and ritual life in the villages—-had also been kept. ${ }^{4}$

The first document to systematically address the organization of the Goan villages was the Foral of 1526 . This compiled a selection of the "uses and customs" of these villages relating to the rules that governed them, particularly concerning the judicial system as well as uses of land and inheritance. Although the most crucial aim of the Foral was to guarantee the tax revenue due to the Portuguese Crown, it also provided a platform of communication between the local villages and the imperial rule by integrating local forms of organization into the imperial order.

Recent scholarship considers the Foral an example of the legal and administrative pluralism that characterized the early modern Portuguese imperial order. The Foral, in this view, translated the "well-knit economic and legal system based on Hindu jurisprudence" ${ }^{m}$ into the Portuguese rule of Goa. This argument can be found explicitly in the work of António Manuel Hespanha, for example, and was later used by Lauren Benton. ${ }^{6}$ This narrative dates back to the 19th century when, in the context of the municipal reforms that took place in Portugal from 1834, Goan elites reacted against the possibility of transposing those reforms to the Goan villages. Filipe Nery Xavier, one of the major figures

2 Duve, "European Legal History - Concepts, Methods, Challenges", 57-58; Rocher, Studies in Hindu Law and Dharmaśãstras, 83-102.

3 Madeira-Santos, "As Instituições Indígenas no Império Português", 278-289; Hespanha, Panorama da História Institucional..., 39-40; Thomaz, "A estrutura político-administrativa do Estado da Índia", 228, 237.

4 On the characteristics of this type of agrarian association in the Western Deccan see Guha, "The Political Economy of Village Life", 83-116.

5 Souza, Legal Systems in Goa, vol. 2, 59-6o.

6 Hespanha, Panorama da História Institucional, 40; Benton, Law and Colonial Cultures, 51. 
of this movement, presented the Foral as the written source of a thousandyear-old form of organization that had not and could not be changed. ${ }^{7}$ Xavier and others-like the Portuguese administrator Cunha Rivara ${ }^{8}$ - converged with two British colonial officials, Charles Metcalfe and Thomas Munro. Metcalfe and Munro also defended the immutability of the system operating in the Indian villages, a perception that found echoes in many other texts of the period. ${ }^{9}$ These two lines of reasoning came together in the publication of an English version of the Foral by B. H. Baden-Powell, seen since then by Goans involved in politics and agrarian debates ${ }^{10}$ as a 'written constitution' of the Goan villages. ${ }^{11}$

In contrast with this narrative, the Foral has also been considered only "a small inroad" to assessing the system that operated in the Goan villages. ${ }^{12}$ Other authors stress the biased nature of the Foral, as it reflected the interests of imperial rulers as well as those of the local elites that constituted the gaunkaris. Moreover, they refer to this document as a 'construction' rather than a 'description'. This argument can be found not only in the work of Carlos Renato Gonçalves Pereira, Paul Axelroad and Michelle Fuerch, Teotónio de Souza, and Sanjay Subrahmanyam, ${ }^{13}$ but also in two unpublished $\mathrm{PhD}$ dissertations and two recent articles which have been fundamental in rethinking this issue. In his thesis, for example, Remy Dias argues that the Portuguese imperial presence stimulated an internal reorganization of the Goan villages, particularly concerning the uses of land, thus impacting the economic power inside the village. For Dias, this process started in the 16th century, with the Foral, and intensified during the 18th century. Later, Manuel de Magalhães called attention to other narratives about the origins of the Goan elites that questioned those presented in the Foral, defending the predominantly imperial character

Xavier, Collecção de Bandos, e Outras Differentes Providencias, 3 vols., passim; Xavier, Bosquejo Histórico das Communidades das Aldeias, 3 vols. 1903-19o7, passim; Xavier, Jr., Collecção das Leis Peculiares das Communidades Agricolas das Aldeas, passim. On that, see also Pinto, "The Foral in the History of Communidades", 191-192. Rivara (ed.), "Foral dos usos e costumes dos Gancares e Lavradores da Ilha de Goa e outras annexas a ella". On this, see Dias, A Socio-Economic History of Goa, 12-18.

$9 \quad$ Inden, Imagining India, chapter 4.

10 See Kosambi, "The village communities in the Old Conquests", 63-78. Baden-Powell, "The Villages of Goa in the Early Sixteenth Century", 261-291.

12 Souza, Legal Systems in Goa, vol. 2, 59-6o.

13 Pereira, História da Administração da Justiça, vol. 1, 59-6o. Axelroad and Fuerch, "Portuguese Orientalism", 439-476; Axelroad, "Living on the edge", 553-580; Souza, Medieval Goa, chapter 2; Subrahmanyam, "O romântico, o oriental e o exótico", 29-43. See also Viegas, As Políticas Portuguesas na Índia. 
of the document. ${ }^{14}$ More recently, Rochelle Pinto argued that the Foral accommodated the "needs of the sovereign" to "the socio-ecological conditions in the region where they were distributed", making it a hybrid document. Catarina Madeira-Santos has likewise stressed the changes in the local order entailed by the writing of the Foral. This author considered it as not merely a register of the local rights, but an expression of an imperial customary law, since the local rights had changed when integrated into an imperial framework. ${ }^{15}$ The Foral, as the first mapping of Goan village order, is, nevertheless, an unavoidable source for those who intend to gain a deeper understanding of the Goan village normativities. While this scholarship confirms that the Foral is, in fact, "a small inroad" to assessing this order, it has not yet said much about its nature. ${ }^{16}$

To better understand the relationship between the villages' normativities and the Portuguese imperial order, sections two and three of this chapter focus on the context of the Foral's production, the contributions from local elites, and the Foral as the first mapping of the Goan villages' order. The following questions thus arise: To what extent does the Foral allow us to assess the local order? How does it describe the local uses and customs? What were the interferences and distortions introduced to local normativities by imperial power through the Foral? And did it contribute to the construction of the normativities that operated in Goan villages from 1526 onward? To contribute toward answering these questions, section four provides a short inquiry into the multinormativity of the Goan order at the time of the Portuguese arrival as well as its past roots.

Following this, the subsequent sections focus on the uses of the Foral and its persistence in changing historical contexts. ${ }^{17}$ Assuming that the Foral was a description of the local political, administrative, and judicial order, how much was it used during the early modern period? Section five focuses on what happened in the territories annexed 15 years after the completion of this document, and whether it fully applied to them. The final section deals with the role

14 Dias, $A$ Socio-Economic History of Goa, 24-25; Magalhães, Pequenos Reis e Grandes Honras, 44-46, 238.

15 Pinto, "The Foral in the History of the Communidades", 185-212; Madeira-Santos, 282.

16 In his PhD dissertation, Manuel de Magalhães (Pequenos Reis e Grandes Honras) argues that the village order replicated, on a micro level, the logics of kingship. Therefore, the head of the village, the main gaunkar, had the authority of and behaved like a "little king" - a thesis that is hard to accept. In the villages under analysis in this essay, seldom are there references to a "main gaunkar". Instead, the reference to gaunkars (in plural) is often found pointing toward a collective rule of the village. 
of the Foral in a Christianized Goa, when the equivalence between generatio (birth) and regeneratio (baptism) transformed the locals into a-kind-of-Portuguese who therefore submitted to Portuguese law. This leads again to the term 'Lusitanization', which was a top-down model and ideal that remained, however, permanently incomplete. Its counterpart, always present, was the indigenization of the Portuguese imperial rule, already expressed in the Foral, many other documents, and many practices, as this chapter also demonstrates.

Before proceeding, some theoretical and methodological issues require attention. The first refers to the almost complete lack of a local written archive for studying the Goan normative order at the time of the arrival of the Portuguese. Besides the European sources, Goan written sources are scarce and archaeological and epigraphic sources are limited when compared with other parts of India, allowing little more than an impression of Goa's past before the Portuguese presence. A 'regional' approach to the history of Goa (i.e., observing these territories as part of a vaster region, the West Konkan, that shared some institutions and historical processes) can be useful to overcome such difficulties. This 'regional' approach thus takes into consideration the findings of the vast anthropological literature on this part of India as well as the processes of construction of colonial knowledge, of which the work of Bernard S. Cohn, among others, is fundamental. Second, connected to this, a 'subaltern perspective' is also needed; that is to say, these processes are analyzed by taking into consideration not only the 'voices from below', but also the local dynamics that existed and persisted within and beyond the Western imperial framework. Finally, these two approaches relate to recent scholarship on the legal history of India, some of which is referred to in this chapter. ${ }^{18}$ In addition, this chapter is also inspired by comparative and connected methodological perspectives, favoring the relationship between the Portuguese empire and Indian polities as well as their relationship with the Spanish and the British empires. A final methodological issue refers to the use of the words: 'Goa', 'Goan(s), 'Hindu(s)', 'India,' 'Indian(s)', 'Europe', 'European(s),' 'Muslim(s)', and even 'Portuguese.'19 Although it is problematic to use these terms when speaking of the 16th and 17th centuries since they refer to identities that did not exist then as they are recognized today, they are nevertheless used throughout this chapter to facilitate understanding.

18 Besides Cohn's Colonialism and its forms of knowledge, the scholarship on these issues is so vast that it cannot be referenced here. An example of the combination of all these approaches applied to the Portuguese empire in early modern India can be found in Xavier and Županov's Catholic Orientalism.

19

In his recent book Os Filhos da Terra, António Manuel Hespanha discusses thoroughly what "being Portuguese" could mean in this period, questioning the uniformity of the concept. His findings are extremely relevant to the discussion of the concept of 'Lusitanization'. 

Portuguese Rule in Goa

Afonso de Albuquerque, governor of the Estado da Índia between 1509 and 1515 , conquered Goa in 1510 and established somewhat of a feudal pact with his Indian ally, Timmaya. ${ }^{21} \mathrm{He}$ assigned him with the offices of aguazil-mor (chief judicial and administrative officer) and captain-general of Goa, in exchange for the defense of Goa, the representation of the Hindu population's interests and 6o,ooo pardaos of gold per year. Later, Malhar Rao, ${ }^{22}$ brother of the King of Honavar (and later himself the king), acquired the same offices in exchange for 40,0oo pardaos of gold. ${ }^{23}$ Sources from 1510 say very little about the political and administrative organization of Goa. It is likely that locals retained their ways of living, as was common in suzerainty, a term Luís Filipe Thomaz used to characterize this initial period. ${ }^{24}$ Through these pacts with Timmaya and Malhar Rao, the Portuguese recognized the property rights of the 'collaborationist' locals and did not ask for more taxes than the ones they had previously paid to the Bijapur Sultanate. Local populations were probably accustomed to this kind of situation since, as in other parts of South India, it was common to produce contracts between the ruler and his interlocutors. This allowed the conservation of local chieftains as well as the sharing of political, administrative, judicial, and fiscal power. ${ }^{25}$

Later, this pact was terminated and, by 1515 , King D. Manuel I (1495-1521) decided to adopt the procedures of the "kings and lords of the land from the time of the Moors" to govern the territories of Goa, but it is unclear if these procedures were Muslim at all. ${ }^{26}$ The territories of Tiswadi, Diwar, Chorão, and Jua (which included the town of Goa) had only been under Muslim rule for 40 years. They knew 20 years of Bijapur dominion (1490-1510), another 20 of Bahmanid rule (1470-1490), and a dispersed dominion, during the 14th century, of the Delhi Sultanate. Bijapur classified the territories of Goa as Muāmala, i.e., lands belonging to the Sultan. A havaldar - the governor — ruled them, helped by a thānedār (the chief fiscal and police officer, who became tanadar in the Portuguese documents) and a Deshpande (the general scribe). All of them

$20 \quad$ This expression is inspired by Luis Filipe Alencastro's essay, “The Apprenticeship of Colonization". On that, see also Guerra, "L'État et les Communautés: Comment Inventer un Empire".

21 Timoja in the Portuguese sources.

22 Mel Rao in the Portuguese sources.

23 Shastri, "Gersoppa's hand in the capture of Goa", 39-42.

24 Thomaz, "A estrutura político-administrativa do Estado da Índia", 228.

25 Magalhães, Pequenos Reis e Grandes Honras, 26.

26 Madeira-Santos, "As Instituições Indígenas no Império Português", 273. 
mediated the relationship with the villages of the region of Goa, a function that was later assumed by the Portuguese tanadar. Judicially, the Sultan was the final authority of the Qazi court, while regionally there were courts presided by vizirs and amirs.

The impact of Muslim rule was undoubtedly more substantial in the town of Goa than in rural areas. Still the Portuguese documentation identifies village institutions and officers that were also present in other territories of the Sultanate of Bijapur, like the muqqadam, the kulkarni, and the nayak. ${ }^{27}$ It is also telling that the names of these offices were of Persian, Konkani, or Marathi origin, demonstrating that Bijapur rule already adopted offices and institutions that existed before their domination of Goa. ${ }^{28}$ Thus, adoption of the procedures of the "kings and lords of the land from the time of the Moors" meant to adopt previous political and administrative experiences that were already plural, of which only the most recent was visible to the Portuguese in the first years after their arrival. This means that King D. Manuel I's statement was the result of the Portuguese's ignorance of the long and complex history of domination of these territories.

This (apparent) respect for local differences represented the initial pluralist political and legal culture of the conquerors. António Manuel Hespanha demonstrated long ago that, in what concerns the early modern Portuguese kingdom, the law of the Crown coexisted with and was sometimes complementary to other types of law, such as local law and the jurisprudence of the courts. Similarly, sovereignty was shared, in contrast to the monopoly of the Crown, which would characterize later periods. In this initial period, these principles somehow translated into the imperial territories in respect of the local institutions. In the legal arena-like in other parts of Europe and the Hispanic world ${ }^{29}$ - the local/corporative norms had precedence over the law of the king if they conformed to the ratio juris or the morals of the Christian religion. ${ }^{30}$ Again, this was a political and legal culture that somehow converged with the situation in early modern India: in cases of dispute between the prescriptions included in the Dharmaśāstras and local customs, the latter often prevailed in the moment of making judgements.

Fukazawa, "A Study of the Local Administration of Adilshahi Sultanate (A.D. 1489-1686)", 37-66; Fukazawa, "Rural servants in 18th century Maharastra. Demiurgic or Jajmani System?" 14-40; but also in Kulkarni, "The Indian village with special reference to Medieval Deccan (Maratha county)", 1-42.

28 Gune, The Judicial System of the Marathas, xxii-xxviii.

29 Agüero, "Local law and Localization of law. Hispanic Legal Tradition and Colonial Culture", 101-130.

Hespanha, Panorama da História Institucional e Jurídica 3, 20-22. 
The practice of compiling uses and customs was renewed in early modern Europe through the long-distance voyages that sought to find better routes to the Indies. During the 16th century, identifying the uses and customs was familiar not only to jurists, but also to travelers, merchants, missionaries, and humanists interested in mapping such uses and customs of the 'newly discovered' parts of the world. In 1520, for example, Johannes Boemus published an Omnium Gentium Mores, Leges et Ritus, arguing for its usefulness. Boemus' book did not yet include the information assembled by the Portuguese and the Spanish as a result of their overseas expansion. ${ }^{31}$ Similarly, travelers, merchants, and officers of the Portuguese Crown compiled the uses and customs of the Indian societies since the beginning of the 16th century. Letters, reports, or treatises like the one of Duarte Barbosa of 1516, "Descrição das Terras da India Oriental, e dos seos Uzoz, Costumes, Ritos e Leys", the Summa Oriental of Tomé Pires of 1515, and the Chronica de los reys de Bisnaga, of Domingos Paes about Vijayanagar were included. ${ }^{32}$ In contrast with the jurists, who were more interested in the uses and customs that overlapped or complemented the field of the ius commune, these actors mainly inquired about other normativities: social, religious, and ritual. ${ }^{33}$

To record and keep these uses and customs - which were, from a jurist's perspective, the "practices followed by most members of the community for a sufficient length of time to become binding" ${ }^{34}$ and recognized as ius proprium - the Portuguese Crown had first to know them. It was in this context that several royal letters, laws, and decrees, issued between 1510 and 1526 , tried to map the new territories and their people. In the same decades, when the jurists of the School of Salamanca theorized about the nature of the relationship between the Spanish monarchy and its non-Christian subjects, Portuguese practitioners in early modern Goa were building this relationship based on their Iberian cultural encyclopedias and experiences. The main issue at stake then was to identify which were the political, administrative, and judicial bodies that operated locally. This was crucial for grasping which taxes were paid by the inhabitants of Goa, as well as identifying which local structures could be integrated into the imperial order. ${ }^{35}$

The rules of João Machado, the captain and the thānedār of Goa in 1515, are exemplary of the initial efforts of the Portuguese Crown. Acquainted with the

$31 \quad$ Boemus, Omnium Gentium Mores, Leges et Ritus, S. Grimm \& M. Wirsung, passim.

32 Paes, Chronica dos Reys de Bisnaga, passim.

33 On this literature, see, maxime, Lach, Asia in the making of Europe, vol 1.

34 Herzog, A Short History of European Law, 124-130.

35 Miranda, "The center and the periphery in the administration of the Royal Exchequer", $1-14$. 
Sultanate of Bijapur, Machado had to figure out the best way of exacting taxes from the farmers of Goa. These would be registered in a book and should be the same they paid to the previous 'lord of the land' (the Sultan of Bijapur). Four years later, the new thānedār, Duarte Pereira, received a more detailed set of instructions. First, Pereira had to count the gaunkars (the elites of the villages) that lived in Tiswadi, Chorão, Dívar, and Jua. Then, he had to identify their lands and the taxes the villages paid, which lands belonged to the Muslims, as well as which were small or damaged. Finally, he should know which gaunkars sold their properties or moved from one village to another, "as they were used to doing", so he could prevent them from doing so. Pereira also had judicial powers: he was supposed to settle the disputes between these gaunkars on issues related to their lands, trees, and plantations. Furthermore, he had to travel twice a week to the island of Tiswadi, accompanied by guards, to watch over it so that no one would steal fruits from either the king's or the gaunkars' trees. ${ }^{36}$

While Pereira was doing this, the "Rules for the government of the town" of Goa, of 1519, stated that the city councilors should know the ordinations of the towns and villages, preserving them when useful and amending them if bad. ${ }^{37}$ This understanding conformed to paragraph 29 of volume one of Ordenações Manuelinas, which established the preservation of local customs unless the king decided to alter them. Article 66 clarified, however, that while each municipality explained its 'old rules', the Crown only kept those that were 'good', excluding those that were inconvenient. ${ }^{38}$ Unfortunately, there are no traces of these early compilations that witness the effort of knowing the land and synthesizing the uses and customs of Goa already in the second decade of the 16th century. The same principles that guided Machado and Pereira's activities were present in the rules of the next thānedār, the powerful Goan Brahman Krishna, ${ }^{39}$ who was now supposed to keep the information collected in a book divided into different sections, each one concerning a different village. ${ }^{40}$

These were indeed times of the 'apprenticeship of the empire', in which the Portuguese agents were slowly delving into the Goan local order, attempting

$36 \quad$ APO, Fasc. 5 , vol. $1,35^{-36}$.

37 APO, Fasc. 2, 20-27.

38 Hespanha, Como os Juristas viam o mundo, 2.4.1.2. Posturas, costumes locais e lei.

39 Crisná in Portuguese. The choice of Krishna demonstrated the dependency of the Portuguese Crown on local collaboration. Moreover, it allowed, at least theoretically, depending on the genuine political loyalty of Krishna to the Portuguese, easier access to the local people and their dealings.

APO, Fasc. 5, vol. 1, 65-68; On that, see Rochelle Pinto, "The Foral in the History of the Communidades", 203-204. 
to grasp it intellectually, in a process that increased in the following decade. When Viceroy Vasco da Gama was sent to India in 1524, accompanied by a new team of officers, with the mission of correctly organizing the administration of the Estado da Índia, he inherited the results of these processes of learning and recordings of local uses and customs from the previous decade. ${ }^{41}$ Among the officers that arrived in India in 1524 was Afonso de Mexia, who had extensive experience as an officer of the king (he had been one of the royal scribes, as well as a scribe of the Royal Exchequer). Mexia would substitute Pedro Nunes in the office of Vedor da Fazenda, the institution that oversaw all the economic and fiscal matters of Estado da Índia and supervised the thānedār as well.

\section{Local Uses and Customs and Imperial Order in the Foral}

It was on the 16th of September of $15^{26}$ that the Foral was concluded, signed by Mexia, and made public. ${ }^{42}$ Another document written by Mexia reiterates that the Foral had, above all, fiscal goals. He explained that he had seen the papers of thānedār João Machado and inquired about the rents to be paid by the villages. ${ }^{43}$ As Susana Münch Miranda has pointed out, tax revenue-and the establishment of institutions that allowed it in the politically subjugated territories - was "a means of establishing sources of revenue" that enabled the king "to ensure the self-sustainability of the crown's intervention in Asia". 44

The first part of the Foral (today lost) materialized this endeavor, critical in a moment when the inhabitants of these villages were not Christian. The Portuguese Crown did not have the right to extract from them the tithes that Christians of other parts had to pay. Without tithes, other tribute payments and rents, namely the foros (one-fifth of the agrarian rents) the villages had to pay to the Portuguese Crown, became more important for the financial sustainability of the Portuguese presence in Asia. The first part of the Foral was in harmony with the process known as Reforma dos Forais, during which almost 500 forais of the Portuguese kingdom were rewritten between 1495 and 1520. These forais also aimed to control the tax revenue to be paid by the Portuguese municipalities and villages to the Crown. ${ }^{45}$

\footnotetext{
41 Apud Loureiro, "Reconstituição da documentação produzida por Afonso de Mexia", 22.

42 APO, Fasc. 5, vol. 1, 114-117, 139-141; Magalhães, Pequenos Reis e Grandes Honras, 58.

43 APO, Fasc. 5, vol. 1, 133-134.

44 Miranda, "The center and the periphery in the administration of the Royal Exchequer", 3.

45 Coelho, "O Poder Concelhio em tempos medievais", 19-34; Neto, "O foral manuelino de Porto de Mós", 77-78; Oliveira, "O Foral de Faro e a Reforma dos Forais", 14-15.
} 
In contrast with the new forais of the kingdom, the Foral had a second part that compiled the uses and customs of Goan villages. However, its encounter with alterity was more challenging than the ones faced by medieval and early modern European royal agents and jurists. In India, the Portuguese faced different forms of social organization, languages, religions, and uses and customs, of which Goa was only a small part. The process of knowing and assembling local uses and customs for the Foral was simultaneously similar and different from previous experiences in the kingdom and in Europe since it adapted the Foral, as Pinto remembered, to the "socio-ecological conditions" of the region of Goa. ${ }^{46}$ Moreover, relying on information previously collected, Mexia also included documentation produced in the context of (and prior to) the Bijapur Sultanate, and information found in old books, registering the nemos (decisions of the gaunkars) on economic and fiscal matters. ${ }^{47}$ The Foral also included fresh information provided by the gaunkars and the scribes of the villages, many of them of Brahman origin. Mexia and his officers thus had many cultural, legal, and administrative resources to draw on when compiling the uses and customs of the Goan villages.

As a "socially embedded community", South India's Brahmans' presence was usually constituted in temples, lineages, referential books, and ritual practices. ${ }^{48}$ The same can be said for the territories of Goa, where the presence of Brahmans was significant. ${ }^{49}$ A copper plate of 1391 reported that Madhav Mantri, Goa's governor under the rule of Vijayanagar, had founded a brahmapuri (a learning place inhabited by Brahmans) on the island of Diwar. ${ }^{50}$ In 1510, the brahmapuri of Diwar was still very active, described by the Portuguese as the equivalent of the "Holy Land" for the local populations or Rome for the Christians. ${ }^{51}$ Brahmans of Kushashtali in Salcete worked as scribes during the rule of Vijayanagar too, as well as in the Bijapur Sultanate in the late $15^{\text {th }}$ and early 16 th century. Their involvement with these royal courts allowed them to reinforce their local and regional positions, expressed, for instance, in the donations they made to their temples. ${ }^{2}$ Kushashtali, as well as Keloshi in its neighborhood, had

\footnotetext{
46 Pinto, "The Foral in the History of the Communidades", 187, 195.

47 Viegas, As Políticas Portuguesas, 47.

48 Fischer, Hindu Pluralism, 13-14. See also Rao, Cultures of Memory in South Asia, 307.

49 On that, see Xavier, A Invenção de Goa, 279.

50 A summary of this copper plate, translated into Portuguese, can be found in Barros, Décadas da Ásia, vol. 2, 188.

51 Documentação para a História do Padroado Português do Oriente (henceforth DHMPPO), vol. 7, 85. See Xavier, A Invenção de Goa, 267, 289-296.

52 Pereira, Gaunkaris, 95; O'Hanlon and Minkowski, "What makes people who they are?", 381-416; Rao, Shulman and Subrahmanyam (eds.), Textures of Time, passim; Alam and Subrahmanyam, "The making of a munshī", $185^{-209 .}$
} 
Brahmanical centers of learning. Their pundits wrote versions of well-known epic poems Mahabharata and Ramayana, adapting the stories of Pandavas, Kauravas, Rama, and their brothers to the territories of Goa. Rescued and transcribed by the Jesuits, these few texts that survived the destruction campaigns of the mid-16th century witnessed the presence of dharma - the moral world of the heroes of Mahabharata and the Ramayana -in the Goan territories. ${ }^{53}$ They also testify to the creative appropriations of 'classical texts', as well as the capacity of local Brahmans to disseminate their worldviews and, to a certain extent, what some scholars called their "regulatory project". ${ }^{4}$

As shown below, the gaunkars and scribes involved in the production of the Foral did not provide all the information they had about their uses and customs, namely those concerning the laws of inheritance. When later questioned, they argued that this was due to the rush with which Mexia had pursued the inquiry. ${ }^{55}$ Another explanation, however, is that the concealment of specific dimensions was intentional and sought to preserve their normative autonomy. It is also plausible that this was the result of (un)expected misunderstandings, ${ }^{56}$ interpreters were involved in the translation of the local language and political and administrative categories into the Portuguese ones, and they could have mistaken the intentions of both parts. ${ }^{57}$ There was neither a wholly bottom-up control of information nor a top-down one in the production of the Foral.

Each of the participants in the process somehow interfered in the final arrangements of the document, which made it into somewhat of a bridge between the village order and the imperial one. Parts of the Foral clearly express the command of the Portuguese Crown, while others show the local elites' ability to defend their interests. Above all, the Foral was not only a hybrid document, but also a monument to a particular historical context, which, for several reasons, was later generalized.

53 Sama, Koṃkan̄i Rāmāyaṇa, passim. Also a Shri Krishnachavitrakatha was written in this period, today in the Archives of Braga. See Gomes, Old Konkani language and literature, $5^{\mathrm{O}-54}$. On the appropriations of the Mahabharata, see Pollock, The Language of the Gods in the World of Men, 223-237.

54 O'Hanlon, Minkowski, and Venkatkrishnan, Scholar Intellectuals in Early Modern India, Introduction. On these appropriations in early modern India, see, in general, Davis, jr., and Brick, "Social and Literary History of Dharmaśãstra - Commentaries and Legal Digests", in Olivelle and Davis (eds.), Hindu Law: A New History of Dharmaśãstra, 33; Mitchell, "The Practice of Hindu Law", 58-77. Lubin, "The theory and practice of property", 13.

55 APO, Fasc. 5 , vol. 1, 157 .

56 Galindo, "Legal transplants between time and space", 134 onwards.

57 Couto, "The Role of Interpreters, or Linguas, in the Portuguese Empire During the 16th Century", 1-10; Flores, "Le «língua» cosmopolite", 225-250; Deshpande, "Scripting the Cultural History of Language", 62-86. 
How did the imperial agents interfere in the contents of the document? And how did these interferences contribute to constructing a new local order? The preamble of the second part of the Foral openly assumed the interference of the Crown by indicating that it assembled the "rights, uses, and customs" of the villages, which "we [the Crown] should keep". Further, those "rights, uses, and customs" were to be used in the manner the agents of the Portuguese Crown found appropriate. The appropriated institutions were, in this case, the existing political and administrative bodies, the gaunkari, and the members that composed them, the gaunkars. The latter, defined in the Foral as governors, ministers, and benefactors, belonged, the Foral said, to the lineages of the founders of the villages. They constituted the collective organism that headed the village, the gaunkari, which governed, as already mentioned, the land and rituals associated with it. The gaunkari also defined access to the privileges annexed to the gaunkar's and other officers' lineages (the vangad), each one usually living in specific quarters of the village. In addition, the gaunkari had judicial powers, settling, in general, the disputes among villagers. It was up to the gaunkari to make the decisions that bounded all villagers collectively.

However, contrasting with the Foral's explanation, possibly provided by the gaunkars themselves, most of the 16th-century gaunkars did not descend from the founders of the villages. An 11th-century document, for example, shows that a man called Chadamma received, as a grant, the village of Morumbi, perhaps at that time already depopulated. In 1526 , the gaunkars of that village belonged to several lineages, but Chadamma's was not part of them. Chadamma's case, like others, is consistent with the narrative about the foundation of Goan villages presented in the Décadas da Asia by João de Barros, who argued that none but three of the lineages that controlled the gaunkaris of Goa were descendants of the founders. ${ }^{58}$ The Foral's narrative also did not consider the gaunkars that had abandoned their villages after the Portuguese conquest of Goa, settling down in the lands of the Sultanate of Bijapur. The Crown expropriated their lands, which were received either by relatives or, in their absence, by other people, who occupied their positions in the gaunkari. ${ }^{59}$

By assuming that the actual gaunkars descended from the founders of the villages, by recognizing new gaunkars, and by making their powers and honors permanent, the Crown crystallized for the future a situation that was not necessarily descriptive of the villages' past. As Pinto has pointed out, this perpetual

\footnotetext{
58 Moraes, Kadamba Kula, 400; Barros, Décadas da Ásia, vol. 2, 190-191.

59 Paragraphs 17, 18, 40 of the Foral; APO, vol. 5, 25. If they returned to their original villages, they could be given other lands that were vacant at that moment (APO, vol. 5, 25).
} 
association reinforced the internal power of those that were the gaunkars at the time the Foral was written. ${ }^{60}$

It is likely that the Portuguese agents were merely pragmatic in applying to the villages of Goa the principle of indivisibility that operated in the kingdom since the Lei Mental in the previous century. This principle stated that honors and jurisdiction should not be separated (dignitates et jurisdictiones non dividuntur). In the early kingdom, this principle had helped to tie powerful families to the Crown, settling an interdependency between both. ${ }^{61}$ In Goa, where the weakness of the power of the king and the lack of human resources was evident, the adoption of this principle was a way of attracting the loyalty of the village elites to the imperial power.

Besides expressing the shared and the specific political culture of each Portuguese agent, this arrangement also converged with the mutual dependency of the ruler and the local chiefs that characterized many South India polities. In these polities, dāna (gifts) in the form of mānya (rents, plus honor and ritual supremacy, namely the right of heading the ritual sacrifices) and rakșana (protection) were exchanged for taxes. ${ }^{62}$ The protection of the elites in exchange for their loyalty was essential to the conservation of the imperial power, particularly in what concerned the fulfilment of fiscal duties. It was the gaunkars' duty, the Foral said, to pay to the "Lord of the land", the taxes each village already paid to the previous ruler. Many paragraphs are concerned with this aspect, while others, directly or indirectly, also refer to tax revenue and the rights of the Crown concerning the immovable and movable properties of the villages and their inhabitants. ${ }^{63}$

In other matters, the power of the gaunkars was reshaped and/or reduced. Several clauses concerning other aspects of the relationship between the gaunkars, the gaunkari, and the imperial power make it evident: their almost complete submission toward the thanedar; their obligation of hosting the officers of the king when they wanted to stay in the village; their commitment to providing services to the city of Goa when asked to do so; and their obligation of registering their decisions by following writing protocols in use in Portugal. ${ }^{64}$

The Foral also prohibited the gaunkars from exercising dāna, an essential part of the social recognition and ritualization of their power, in their

6o Pinto, "The Foral in the History of the Communidades", 188, 211-212.

61 Hespanha, Como os juristas viam o mundo, 2.4.3.7. Transmissão dos direitos senhoriais.

62 Magalhães, Pequenos Reis e Grandes Honras Culto, 23-25, 34.

63 Foral dos usos e costumes, paragraphs 3-6, 9-10.

64 Foral dos usos e costumes, paragraphs 11, 14, 18, 21, 36, 37, 39 . 
relationship with the king's officers. This prohibition referred directly to paragraph 56 of volume 4 of the Ordenações of King D. Manuel I, which tried to control practices which we today identify as corruption. However, locally it meant stripping an essential part of the expression of their power. The interference in the symbolic authority of the gaunkars was present in other moments too. On the one hand, the governor had to authorize the use of torches and palanquins by new gaunkars, as well as pedestrian officers to accompany them, increasing their dependency on the imperial power. On the other, harvest rituals had to include a Christian vicar and a presentation of rice in the cathedral, reducing the religious autonomy of the village. ${ }^{65}$

All these cases demonstrate that the Foral definitively reshaped the local political and administrative order. The gaunkars continued to be the heads of the villages, as well as responsible for the decision-making. At the same time, some of their honors were abolished, increasing their dependency on the Portuguese Crown. Furthermore, their administrative processes included some procedures that followed the Portuguese style. In addition, the Foral also insisted on the need to maintain the local uses and customs; the expressions "following their uses and customs" or "general customs" are frequently invoked. Moreover, the Foral stated that the customs of villages that had different customs should be respected as well. Thus, which local uses and customs were kept and how were they kept?

Again, the gaunkars were the main interlocutors, and they certainly tried to keep the customs that were most favorable to them, expressing, in practice, what Sumit Guha has argued: that "custom would favour the powerful whose predecessors had made it".66 The Foral kept their customary privileges of leasing paddy fields as well as of granting wastelands if they were to be used to cultivate betel trees. The same happened with the grants they gave to the village officers-priest, dancers of the temple, clerk, porter, washman, shoemaker, carpenter, blacksmith, renter, 'faraz', cleaner-as payment for their services to the village. The taxes to be paid by each type of land - paddy fields, areca tree orchards, wastelands - were also preserved in conjunction with the principle that the gaunkars should not pay more to the Portuguese king than they did to the previous ruler. ${ }^{67}$ However, according to John Duncan Derrett, those concerning inheritance were influenced by the Yäjñavalkya Smṛti (the second

65 Foral dos usos e costumes, paragraphs 19, 27-29, 45 and 49; see also Pinto, "The Foral in the History of the Communidades", 209-210. It was the Portuguese law that was applied in the cases of usury and thefts (clauses 25, 26) referring to Ord Man, L v, tt. XXXvII - Dos furtos...; Leis Extravagantes, tt. III - Dos furtos \& Roubos; OrdMan, L IV, tt. XIV - Das usuras.

66 Guha, "An Indian Penal Regime", 106.

$67 \quad$ Foral dos usos e costumes, paragraphs 5, 6, 9, 10, 12, 20. 
most crucial 'legal' smrti after the Manusmrti), through the commentaries of Vijñaneśvara and Aparāditya I, as well as of Parāśara Smṛti by Madhāva. Derrett found this influence in a dispute taking place between Hindus in the first decades of 18th-century Goa, where "Goan customary law" was recalled. ${ }^{68}$ If this 'classical' inspiration was still present at the beginning of the 18th century, two centuries after the Portuguese influence, it was probably more visible in the previous centuries and thus expressed in the Foral.

The judicial system inscribed in the Foral also followed the local customs. Many of the legal situations referred to were to be solved by the gaunkari. Modes of proof-documents, witnesses, oaths-were similar to those operating, in general, in the Indian world. However, if classical Indian legal texts treated legal procedures very carefully (like the inclusion of other modes of proof, such as 'possession' and 'ordeals'), the information included in the Foral was sketchy in what concerned legal procedures. In litigations between inhabitants of the village related to immovable properties and inheritance, the Foral required the annexation of the deeds (rājaśāsana or other documents) and the books of the village concerning the object of litigation. Also, the procedures related to mortgages, their amounts, and types of proof needed to solve litigations between creditors and debtors retained the local ways of solving conflicts.

The same did not happen, however, in the cases involving significant misbehavior by the gaunkars. In those situations, it was the thannedār, or even the captain-general or the governor or viceroy (the ultimate judicial officer of appeal), who decided what kind of punishment ill-doers would receive. However, this could also reproduce a local practice, since at least under the Bijapur domination, the Sultanate regional courts or the Sultan himself solved harsh criminal cases.

The pages above illustrate how difficult it is to reconstruct the village normativities through an analysis of the earliest available document that systematically maps some of them, especially concerning the political, administrative, and judicial spheres. Besides being a selection of norms, the Foral also witnesses the hybridity of the norms it contained. Admittedly, parts of them already operated in the villages, as a result of prior experiences, but others were the outcome of negotiations between the rulers and the ruled. Writing down the results of these negotiations was novel and made of the Foral, in a sense, a 'written constitution' of the village normativities, though not in the sense scholarship has traditionally attached to this word. Instead, the Foral did constitute a kind of new village order, which was the result of older norms and practices and imperial selections and impositions.

Derrett, "Hindu law in Goa", 206, fn. 6. 


\section{Dharmaśāstras and the Smṛti in the Local Order of Goan Villages: The Multinormativity of the Foral}

Stepping back in history can be enlightening in what concerns the potential sources of some of the normativities that were considered old uses and customs. The medieval territories of Goa were under the dominion of polities that had the Dharmaśāstras and their commentaries as part of their world of normative reference. The Western Chalukyas (1076-1156), the Goan Kadambas (1006-1356), and the Vijayanagar empire (1370-1469) were all under Brahmanical influence and promoted the commentators of the ancient texts.

It was during the Chalukya government of Vikramadatya VI (1076-1126) that the Brahman jurist Vijñaneśvara wrote the Mitạșksāra, the most famous and most widely disseminated commentary on the Yagnavālkya Smrti. By that time, the Goan territories were under the rule of the feudatory Jayakesi II, who was the Kadamba räja of Goa between 1125 and 1147 and husband of one the daughters of Vikramadatya Vi. ${ }^{69}$ More or less in the same period, the Apārarka-another treatise on the Yagnavālkya Smrti-was written by the ruler of the Silaharas, Aparaditya I (1170-1197), a polity of the north Konkan in the vicinity of Goa. ${ }^{70}$

It is still not possible to trace a direct link between these treatises and the customs included in the Foral that seem to refer to them. Still, the Brahmanical influence in the Goan territories since the 11th century allows us to suspect that they might have had an impact in these territories. In that century, for example, donations to Śivaite Brahmans reinforced the impression of a Brahman influence among the elites of medieval Goa. Those Śivaite Brahmans established centers of learning (agrāharas), where the Védas and the schools that interpreted them (the Mìmāmsāa, Nyāya, Sāmkhya, Yoga, and Vedānta, which was the last and the one that prevailed in 16th-century South India), were studied. ${ }^{71}$ Similarly, other 'classical' texts - the Dharmaśāstras, the Itihāsas, and the Purānas - were taught, through methods of exegesis and analysis comparable to the Scholastic tradition in Europe. ${ }^{72}$

69 Mitāṣksāra became one of the most important medieval digests, translated into Tamil, Telegu, and Persian, at least. Another well-known digest was the Dāyabhāga, a treatise written by Jĩmũtvahāna of Bengal of the 1oth to 11th centuries, which proposed different interpretations concerning inheritance, property rights, women's rights, and other matters.

$70 \quad$ Kane, History of the Dharmaśãstras, vol. 1, 374-375.

71 Fischer, Hindu Pluralism, 5-6.

72 Moraes, The Kadamba Kula, 287-30o. On that, see inscriptions from the time of the Kadambas in Epigraphia Indica, vol. 7; Herzog, A Short History of European Law, 78-79. 
As Derrett has pointed out, some of the inheritance customs assembled in the Foral might have been local appropriations of the Mitäșksära. The principle that inheritance was due to the kinship between the owner of the wealth and the heir of it (father, son, grandson, and vice-versa) — what Vijñaneśvara called "unobstructed heritage"-ruled the majority of the succession norms present in the Foral. ${ }^{73}$ Similar situations can be found in the clauses about the sale of land. Selling land was complicated since the agreement of all its heirs and other gaunkars was needed; in addition, cancelling the sale was also possible. ${ }^{74}$ The same could be said concerning the Mitạsksāra for the rules toward women, who were entirely unable to inherit from their fathers, grandfathers, and husbands. ${ }^{75}$ Finally, the norm that stated that if any goods were "discovered" or "found", they belonged to the king, could also refer to Mitāșksāra (or other treatises) paragraphs on forms of acquiring property. ${ }^{76}$

It is still unknown whether such uses and customs were transmitted orally or in writing. Documents produced under Portuguese domination in the early 16th century do refer to the existence of ancient scriptures and books of law in the villages of Goa. Were these books simply compilations of uses and customs without reference to the classical treatises, as some scholarship argues? Or were they mere apocryphal documents used to impress the new rulers? Many scholars contend that, instead of a normative textual tradition based on the Dharmaśãstras and the Smrtis, customs were "the main source of court decisions", "which decided case by case without taking into consideration any normative text".77 Practice and jurisprudence, not books, defined multiple and casuistic judicial architectures, where the very concept of enforceable law

73 Foral dos usos e costumes, paragraphs 22 and 30 . However, the interference of Portuguese law was also visible in these sections. The paragraphs concerning the heritage of those dead without heirs provide an excellent case to observe: the inheritances belonged to the king, but he allowed the gaunkars to use or distribute them to other people.

Foral dos usos e costumes, paragraphs 15 and 16.

75 Foral dos usos e costumes, paragraphs 27, 30, 33.

76 Foral dos usos e costumes, paragraph 32. See Dāya-Bhāga and Mitākșarā, 242; Bhattacharyya-Panda, Appropriation and Invention of Tradition, 21-22, and Rocher, Jimutavahana's Dayabhaga, 16.

77 Halpérin, "Transplants of European Normativity in India and in Japan", 150-157. These authors bring up examples from 14th-16th century Kerala, where Dharmaśãstras were never quoted. There were places where the sāstric prescriptions were not even invoked. In fact, practical law relied on ācāra, samaya, and maryā $\bar{a}$, all words referring to customs and practices, without reference to the śãstras.

Davis, "Dharma, Maryāda and Law in Early British Malabar", 83, 119, 149 and 204; the Manu Smrti was known in the 18th-century courts of the Marathas kingdom. Gune, The Judicial System of the Marathas, 69. A similar understanding of these processes can be found in Guha, “An Indian Penal Régime”, 101-126. 
did not exist. In addition, other scholars have argued that these customs were "epitomes of past balances of social power".78

What was the status of the uses and customs compiled in the Foral? Were they only 'local customs' or, instead, did they witness the appropriation in Goa of the Dharmaśãstras and the Smrtis? Moreover, if the latter is true, can it be said that Tikās and Nibandhas (treatises that were legal commentaries on the Dharmaśãstras) proliferated in 16th century Goa, like in the Islamicized territories of the Deccan or other Indian polities, by the time of the British arrival? ${ }^{79}$ More detailed studies are needed to reconstruct the legal traditions that informed the administrative order of the Goan villages and to understand, with more rigor, the characteristics of this administrative order. Still, the examples presented above allow us to suppose that the village order that materialized in the Foral was constituted by several layers of experience, combining genuinely local uses and customs with local appropriations of classical Brahmanical treatises, transforming their rules into local customs. This diversity was undoubtedly related to the many dominations that had ruled the villages before the Portuguese. The Portuguese were merely another superimposed layer in an order characterized by multinormativity, which even hosted contradictory norms. ${ }^{80}$

\section{$5 \quad$ The Uses of the Foral in the 16th and 17th Centuries}

The coverage of the Foral reinforced its constitutive dimension: the "gaunkars, laborers, tributaries, inhabitants" and other people of the villages and town of Goa were supposed to be attached to its norms. Moreover, even if the document clearly defined its initial normative space-the 31 communities of Tiswadi, Chorão, Dívar, and Jua ${ }^{81}$ — from 1543 it was extended to the inhabitants of the

78 Guha, "Wrongs and rights in the Maratha country", 26; Rocher, Studies in Hindu Law and Dharmaśãstras, passim; Mawani and Hussin, "The Travels of Law: Indian Ocean Itineraries", 735; see also Davis, The boundaries of Hindu Law, passim.

79 Bhattacharya-Panda, Appropriation and Invention of Tradition, chapter 1, 17; Lapidus, $A$ History of Islamic Societies, 361-364; Hallaq, An Introduction to Islamic Law, passim; Coulson, A History of Islamic Law, passim; Davis, "Dharma, Maryāda and Law in Early British Malabar", 51-70; Rocher, "Hindu Conceptions of Law", 1283-1284.

80 On the superimposition and substitution of different layers and the overlapping of sources of justice in early modern India, see Guha, "The qazi, the dharmadhikari and the judge Political authority and legal diversity in pre-modern India: Premodern Europe and India in Comparison (13th-18th Centuries)", 97-115.

81 Pinto, "The Foral in the History of the Communidades", 200-201. 
villages of Salcete and Bardez, which meant that 99 more villages came under its influence. Concerning these territories, a document of 1595 declared that Salcete followed most of the uses and customs of Tiswadi, but it is not clear whether the same applied to Bardez. ${ }^{82}$ In fact, concerning land, for example, a 1619 report explained that all property of Salcete belonged to the ruler, who rented it for short periods to the villages, while in Bardez, the document said it was the inhabitants of the villages who owned the land. ${ }^{83}$ How did these statements unite with the norms of the Foral concerning the land and its ownership? The Foral was imposed on territories and people with different historical experiences, thus freezing the diversity of these experiences in favor of a process of essentialization of village life, which was mainly useful for the relationship between the imperial power and those villages. Was the Foral efficient in this endeavor?

A petition of 1534 sent to the Governor of Goa is particularly enlightening: on the one hand, this petition demonstrates that the judicial system of the village was considered insufficient to solve all conflicts, especially when the solution provided by the village courts did not satisfy one of the litigants. Perhaps this explains why one of the parties involved in the litigation decided to petition to the imperial court. On the other hand, this petition also demonstrates that, by 1534, some local inhabitants started to refer to the norms included in the Foral to settle conflicts between them, even if this discredited the validity of the document in relation to specific situations. ${ }^{84}$

The Sentença sobre as partilhas dos naturaes da terra, signed by the Governor of the Estado da Índia, Nuno da Cunha (1529-1538), on August 14, 1534, refers to a conflict between three brothers: Santu Sinay and Sau Sinay against their half-brother, Ramu Sinay. The conflict concerned the inheritance of their father. Sau and Santu complained about the division of their father's heritage into only two parts, based on the number of wives he had, rather than three, based on the number of sons. Their petition argued that the Foral was insufficient in the clauses concerning inheritance after the death of a father, regarding the rights of the sons, nephews, and relatives, or sons of different wives. They argued that the "books of their antique laws" contradicted the clauses included in the Foral. ${ }^{85}$ To solve this contradiction, the two brothers suggested the governor send the principal officer of justice-the Ouvidor Pedro Álvares

\footnotetext{
82 Paes, Tombo das Ilhas de Goa e das Terras de Salcete e Bardês, 100.

83 ANTT, Armário Jesuítico, Mss. 89, no. 19, 42; AHU, India, Cx 6. no. 29, 1.

84 Pereira, História da Administração da Justiça, vol. 1, 61-65.

85 Jaffe, "The languages of petitioning in early colonial India", 581-597.
} 
de Almeida— to listen to local "lettered men" (probably prāadviveka) ${ }^{86}$ about the various chapters concerning inheritance included in the "books" and "antique scriptures" of the land. ${ }^{87}$

The judicial sentence issued by the Governor did include information provided by "lettered men". They declared that the inheritance, both immovable and movable property, of a deceased father should be equally parted between his sons, though with an advantage for the eldest brother. They also said that the heirs should give some movable property to their mother, for her maintenance. The same principle applied in the case of multiple wives, but only when these were of the same caste as the deceased father. Some of these legal principles were present in the Manusmrti and were repeated in other texts, like the Dharmasutras of Gautama and Baudhāvana and the Smrtis of Yājñavalkya and Nārada. ${ }^{88}$ As mentioned above, these were principles that circulated, directly or indirectly, among Brahmanical communities, and were probably appropriated by the "lettered men" of Goa and its surroundings.

These explanations, however, opposed clause 33 of the Foral, which explicitly stated that in cases with two wives the inheritance should be divided into two equal parts, even if one wife had one only child, and the other, two or more. Consequently, the Ouvidor decided to convene an assembly of the gaunkars, who eight years earlier had informed the Portuguese agents about the inheritance rules that operated in the villages of Goa. The Portuguese ruling explained that "the truth of their customs" motivated this decision. The gaunkars validated the two different customs; however, they said that in disputes like that of the brothers, the law was to be followed, thus contradicting the rule that customs had precedence over law. In addition, the gaunkars explained, as before, that they had not given this information to Mexia because he appeared to be in a hurry when questioning them about the rules of inheritance that operated in the villages. ${ }^{89}$

The Ouvidor conducted the process and wrote the conclusions, but the final ruling was Governor Cunha's. He accepted both customs as valid, arguing that both customs were "ancient in this land", and "both were used". He decided for the norm that stated that the inheritance should be equally divided among all sons, independently of the number of wives. He also agreed with the

86 Local expert on the Dharmaśãstras and their legal commentaries (Tikās, Nibhandas), as well as on local customs.

$87 \quad$ APO, Fasc. 5, vol. 1, 156 .

88 Rocher, "Hindu conceptions of law", 39-58; Rocher, "Inheritance dāyabhāga", 172; Kane, The History of the Dharmashastras, vol. 2-1, 472,

89 APO, Fasc. 5, vol. 1, 157 . 
application of the same solution to comparable situations, possibly because this norm was most similar to Portuguese law, where all the sons had equal rights to their fathers' inheritance. ${ }^{90}$ Cunha's decision converged with the tendency to expand Portuguese law — probably considered to embody the ius commune better than any other- to all subjects, in tension with the legal pluralism that was still present at the time of production of the Foral.

This petition and the corresponding decision are unusual for several reasons. On the one hand, the decision of the Governor illustrates a change that was taking place in the political culture of Portuguese elites. Parallel to the traditional pluralist culture, a trend favoring the homogenization of the societies under the rule of the same prince was emerging. Somehow, Cunha already embodied this, which, as will be discussed, had other and more dramatic expressions in the territories of Goa. On the other hand, this case demonstrates that the local elites (at least, Brahman elites) were well aware of the lacunae of the Foral and took advantage of this when possible.

Ultimately, not only were the local normativities more complicated than what was assembled in the Foral, but so was the vocabulary used by the locals to refer to them. The reference to the body of rules that was perceived and translated by the Portuguese as "law" is enlightening. To which "law" was it referring? Why did the Portuguese think that such "law"91 could translate into the Portuguese word lei? The data available are insufficient to answer these questions. We can only hypothesize that the "lettered men" belonged to an agrahara $^{92}$ or brahmapuri, where there was possibly an archive with scriptures in which different customs and laws were compiled.

Like clause 33, other requirements of the Foral were open to interpretation. For example, paragraphs 17 and 18 expressed different customs about the inheritance of gaunkars who had abandoned their land, rights, and obligations. Clause 18 established that the relatives of a fleeing gaunkar inherited his properties, but, if they did not want to accept it or were absent, the inheritance would revert to the gaunkaris. However, clause 17 stated that the gaunkars could give those rights "to whom they want", paving the way for the entrance of other lineages into the gaunkaris, ${ }^{93}$ as was later witnessed in three villages of Bardez (Calangute, Aldona, and Siolim) and one of Salcete (Raia). In these

\footnotetext{
90 APO, Fasc. 5, vol. 1, 158-159. On that case, see also Pinto, "The Foral in the History of the Communidades", 81-82; and D'Souza, Legal Systems, vol. 2, 73-74.

91 We only have access to the Portuguese translation, and not to the original word used by the gaunkars and the "lettered men".

92 Land given by a king or a noble person to Brahmans to maintain their temples and a pilgrimage site and to sustain their families.

93 Foral dos usos e costumes, paragraphs 17, 18, and 33.
} 
villages, people that did not belong to the lineages of the actual gaunkars, but had rents or rights in the village or were powerful creditors, were promoted to the status of gaunkars, constituting new vangads. ${ }^{94}$

In contrast, other clauses were invoked by other gaunkars to counteract either the pressure of these powerful groups that tried to participate actively in the government of the village or, as would happen later, the policies of the Crown. ${ }^{95}$ In 1572 , the king received a collective petition against the public services that the government asked the gaunkars to provide. The gaunkars argued that these demands were against the Foral: Clause 21 established that they should only help in the construction and cleaning of the walls of the town of Goa and similar services. ${ }^{96}$

Seeing that the second part of the Foral, the one specifically related to the uses and customs, was challenged, the same happened with the first (missing) part. In 1533, Governor Cunha asked for the presence of the gaunkars of Goa and asked them to include in the Foral the goddevrad, a tax they paid to the former rulers of Goa. The gaunkars admitted that this tax was absent, declaring that they would pay it henceforth. Six years later, Vedor da Fazenda Fernão Rodrigues de Castelo Branco asked the scribes of the villages to include the culcarna papoxi, another tax they had formerly paid to Bijapur. In 1541, the same officer received information from the Sultanate of Bijapur about the kushvarat, a voluntary tax paid by the villages, calling the gaunkars again to settle this. As a result, an addendum was placed in the Foral, thus raising the taxes paid by the villages. Following this, the kushvarat was suspended by Governor Martim Affonso de Sousa in 1543 and reintroduced by Viceroy D. Luís de Athaíde in 1579, who said that this was to respect the Foral and the agreements made with the gaunkars in 1541 . However, since this tax was only paid since 1579 by the people of Bardez, its Câmara Geral (the assembly of the most important villages of Bardez) petitioned against it, which led Viceroy Francisco de Mascarenhas to suspend it once more until its second reintroduction in $1595 .{ }^{97}$ All these decisions were attached to the original document, making both parts of the Foral a palimpsest of the historical processes taking place in Goa, as well as demonstrating their plasticity. ${ }^{98}$ One of these processes was the Christianization of Goa and its inhabitants.

94 APO, Fasc. 5, vol. 2, 844-846. Vangads were hierarchical divisions within the gaunkar and caste groups expressed in the spatial organization of the village.

95 Magalhães, Pequenos Reis e Grandes Honras, 63, 201.

$96 \quad$ APO, Fasc. 5, vol. 2, 844-846.

97 Miranda, A Administração da Fazenda Real no Estado da Índia, 59, fn. 16.

98 Paes, Tombo das Ithas de Goa e das Terras de Salcete e Bardês, 9-17. 

'Lusitanization' of Village Normativities

The Portuguese elites' political culture had changed significantly by the time of the annexation of the territories of Salcete and Bardez in 1543. The religious conflicts taking place in Europe, at least since the formal excommunication of Luther by Pope Leon X in 1521, increased the political relevance of religious affiliation. The decision-makers feared that the political loyalty of people who did not share the same religion as their king was feeble. Consequently, while in the kingdom there were visible efforts of re-Christianization and to control orthodoxy (the Inquisition was one of the institutional expressions of this) ${ }^{99}$; in the imperial territories, Christianization became an essential tool to guarantee political preservation, particularly in those territories under the direct rule of the Portuguese king.

This change starts to materialize in Goa in the 1530s, already under the government of King D. João III (1521-1557). ${ }^{100}$ The conversion to Christianity and the homogenization of Goa's inhabitants became systematic in the subsequent decades, with dramatic consequences for the life of the villages. The juridical principle that assimilated regeneratio (baptism) to generatio (birth) was associated with the conversion to Christianity and became an instrument of naturalization, that is to say, of 'Lusitanization' of the local people. After baptism, local Christians would enjoy, at least theoretically, the same legal rights and obligations of the Portuguese and they would submit to canon law and its precepts. ${ }^{101}$

It is therefore essential to visit the decade of 1540 to be able to assess the changing world of Goan villages and the transformation of the normativities that governed them. The systematic destruction of the temples, deities, and books of the villages and the expulsion of their priests started in 1540, severing the 31 villages of Tiswadi, Chorão, Dívar, and Jua, from one of their essential dimensions: the religious one. Knowing how the patronage of deities and temples and the performance of the rituals involved in this were relevant to the gaunkars' power, it is easy to deduce how this process of destruction

99 For an analysis of the strategies used by the Inquisition to stimulate and control orthodoxy in Asia, see Lourenço (Chapter 7) in this volume.

100 Xavier, A Invenção de Goa, chapter 1.

101 Documentos Remetidos da Índia, vol. 2, 66-67. The establishment of a High Court in 1544 also helped to enforce the efficacy of the new legislation as well as the reception of the decrees of the Council of Trent, which had been adopted as law of the kingdom since 1564. 
had immediate consequences in the local economy of power. ${ }^{102}$ Twenty years later, the territories of Salcete and Bardez were the object of the same policies, even if this violated the 1555 treaty established between the Portuguese government and the Sultanate of Bijapur that annexed them; this treaty had established that the inhabitants of those two regions should only convert to Christianity with freedom of choice, allowing them to keep their temples, rites, and devotions. ${ }^{103}$

It was in this context of Christianization that Fernão Rodrigues de Castelo Branco wrote a new Foral. This document was mainly concerned with taxes and was probably intended to substitute the first part of the Foral de Mexia. It established that the gaunkars would voluntarily (with "contentment" and without any obligation) pay to the Crown, "every year and forever", 2, ooo tangas brancas taken from the rents of the lands and other properties that belonged to the temples, priests, and other temple servants who had been expelled from Goa. This money was intended to be used for promoting Christianity, the building of churches, convents, and monasteries, and the payment of priests.

The Foral of 1541 recognized that the gaunkars were the owners of those lands and that neither the governor nor the Vedor da Fazenda, or any other officer of the Portuguese Crown, could ever violate those rights. ${ }^{104}$ Curiously, this agreement kept the financial control over the (now Christian) religious world in the hands of the gaunkars, which was essential for the symbolic recognition of their supremacy. This was the case even if only one of the signatories of this agreement (which included the Vedor da Fazenda, Krishna, the thānedār, Loqu Sinai, and Gopu, three of the principal Brahmans of Goa, as well as the gaunkars of 15 villages) was already a Christian.

Although it testified to the increasing interference of the imperial power in the life of Goan villages, this new Foral was also a testimony to a time in which the gaunkars of the villages were still in charge and able to control their most valuable lands. Fifteen years later, an inventory of the properties given to the temples and their servants was made with the help of the gaunkars, who, in general, continued to be Hindu. ${ }^{105}$ However, this situation would not persist

102 APO, Fasc. 5, vol. 2, 508, 612-614; DI, I, 63-89; Priolkar, The Goa Inquisition, 71. At the same time, it was suggested to the viceroy that some powerful Brahman families, like those of Khrisna, Loqu, and Anu Sinai, should be put away in order to facilitate the conversion to Christianity.

103 APO, Fasc. 5, vol. 1, 267-278, 272 .

104 APO, Fasc. 5, vol. 1, 161-170; Paes, Tombo das Ilhas de Goa e das Terras de Salcete e Bardês, $67-75$.

105 APO, Fasc. 5, vol. 1, 286-29o; the lands and rents of the temples continued to be disputed by different agents. For example, in 1603, António Rodrigues, a converted Indian, asked 
for long, as demonstrated by other documents from the second half of the 16th century concerning these lands. ${ }^{106}$

The legal consequences of Christianization for life in the villages were critical. The royal decree of 1542 (confirmed in the following decades and expanded to the territories of Salcete and Bardez) defined the legal and political effects of the conversion of Indians. It openly expanded the privileges of the Portuguese living in Goa to people of "any other nation or generation" that married in Goa and set up house there, provided they were Christian. ${ }^{107}$ This statement- " provided they were Christian" - became a juridical principle that would frame many of the subsequent imperial laws, provisions, and decrees.

Aspects such as marriage, family, orphanhood, women, inheritance, land, residence, labor, ownership, and political rights were now dependent on conversion. For example, conversion by one member of the family meant that inheritance would be regulated by Portuguese law, leading to conflicts among the members of the family regarding inheritance rights. As said before, the sections of the Foral on inheritance excluded women (widows) and daughters from family heritage. ${ }^{108}$ However, Portuguese law stated that Christian women could access their own parents' legacy and take precedence over their non-converted male brothers. Christian widows could marry a second time and receive part of their husband's legacy. In the absence of sons, a man's heritage was divided among wives and daughters that were Christian and among other relatives that had converted to Christianity. Additional legislation against the sati prohibited women from burning themselves "on account of the death of her husband". The Portuguese ordinances would also regulate infidelity, prostitution, and other issues concerning morality. 109

Additionally, a significant number of laws were explicitly discriminatory of the non-Christians, reducing their local power, social status, and economic standing. For example, in the leases of the paddy fields of the villages, Christians had an advantage over non-Christians. These decrees and laws were among many aimed at persuading the locals to convert to Christianity. Ecclesiastical norms, such as decree 27 of the First Provincial Council of Goa (1567), stated that "a non-believer shall not receive office, dignity, honor, pre-eminence, or

for the rents of the temples of the village of Margao, the most important village of Salcete, and received them (APO, Fasc. 5, vol. 3, 1095, vol. 1099) APO, Fasc. 5, vol. 1, 182-183, 218-219, 230-234, 249-254, 330, 336-337; APO, Fasc. 5, vol. 2, 687-689, 835-837; APO, Fasc. 5, vol. 3, 993.

107 APO, Fasc. 2, 115-116; Fasc. 5, vol. 1, 386-387.

108 Foral dos usos e costumes, clauses $28-30$ and 32.

109 APO, Fasc. 5, vol. 1, 171-173, 175, 178, 381-383, 410; APO, Fasc. 5, vol. 2, 543-545, 612, 903-903, 994-996. 
domain over a believer" ${ }^{110}$ In conjunction with this, non-Christians could not own Christian slaves and many Brahmans lost their power positions. These decisions were legitimated by the Relação of Goa, established in 1544 as a court of appeals, which was also charged with reviewing the alvarás and provisions issued by the governors and viceroys. Among these were those related to the advancement of Christianity.111

The Christianization of the economy of power inside Goan villages was gradual, even if many administrative practices were kept. However, a relevant change occurred in the decision-making process: gaunkars who did not convert to Christianity became unable to vote in the gaunkaris or participate in the elaboration of the nemos (the written decisions). This excluded them, in practice, from the government of the communities. The introduction of the Livro das Communidades by the end of the century, with paper coming from Portugal and kept in an arch located in the parish buildings, witnesses the ongoing process of 'Lusitanization' of the village life. From that moment onward, the nemos were registered in these books. The autonomy of the gaunkari also changed significantly. In 1633, the Viceroy Miguel de Noronha issued a provision that explicitly declared the loss of the status of gaunkar and the honors associated with it for all those that did not convert to Christianity. This decision responded to a joint petition by the Câmara Geral, the "Christian people" of Goa, and the "Christian ministers".112

There were also ambivalences concerning some decisions. For example, in 1561 D. Francisco Coutinho allowed the "gentiles" that had departed for Bijapur to return to their villages and receive their lands back. Though contradicting clause 17 of the Foral, this decision was prompted by the fact that many communities were deserted and the paddy fields became uncultivated, which meant significant decreases in tax revenue. ${ }^{113}$ However, Viceroy D. Duarte de Meneses declared in 1585 that Christians could inherit these lands or, in their absence, "whomever the gaunkars wanted" (clause 17), thus reaching a kind of compromise between the Foral and the policy of conversion. Furthermore, in

\footnotetext{
11 APO, Fasc. 5, vol. 2, 319-320, 543-545.

111 Pereira, História da Administração da Justiça, vol. 1, 160.

112 APO, Fasc. 5, vol. 3, 1399-1402.

113 APO, Fasc. 5, vol. 2, 521-523, 543-545. The same viceroy attributed in 1563 all the lands belonging to deceased Muslims, Jews, or "gentiles" without heirs, of all Goa, to the construction of the cathedral of Santa Catarina (because this was one of his priorities) and, in another decree, decided to expel many Brahmans and "gentiles" of Goa that opposed the conversion processes (APO, Fasc. 5, vol. 2, 580-581).
} 
other cases, the Crown protected the rights of the Christian gaunkars, invoking, when needed, the Foral. ${ }^{114}$

The policy of conversion also changed the judicial system that operated in the village. On the one hand, as mentioned above, Portuguese law applied to the converted. On the other, Christian agents gained influence in the judicial sphere of the village. ${ }^{115}$ During the government of Francisco Barreto (15551558), António Martins, the Pai dos Cristãos (Father of the Christians), could solve civil conflicts between Christians and between Christians and non-Christians involving a fine of up to five xerafins. His decisions had no right of appeal as was also the case with his jurisdiction for criminal cases where there had been no blood shed. In 1560, Pius IV's bull, Pro salubri regnorum, renewed for King D. Sebastião (1554-1578) the rights of the monarchy to enlist ecclesiastics in civil affairs, such as judging cases of crime. In an alvará of 1563, Viceroy Coutinho extended this jurisdiction to "the rectors of the parishes and confraternities of the churches" ${ }^{116}$ They could "listen to the Christians of the land and the gentiles, in their conflicts". The fines imposed were up to a certain amount of money and their decisions were not open to appeal or grievance. From 1566 onward, a Judge of Orphans exclusively dealt with the inheritance of the orphans of non-Christians and converted Indians. ${ }^{117}$ Again, a competence previously divided between the gaunkari and the Crown in the Foral was now assumed entirely by institutions of the Crown. In the following decade, a clause required that if the rectors knew "the people in those lands and islands worshipped idols, or engaged in other forms of gentile acts prohibited by the Council", they were obliged to inform the competent judge. This provision ensured that these rectors were charged not only with religious power to resolve matters of minor importance but were also expected to denounce the ill-doers. ${ }^{118}$

However, after an initial period of judicial interdependence between the Crown and the regular clergy, there was a gradual push to revoke the priests' judicial powers. In 1581 , the judicial power of the missionaries in the villages was limited through the creation of the office of Conservador e Juiz dos Cristãos da Terra (Judge of the Christians of the Land). This official had to investigate

114 APO, Fasc. 5, vol. 1, 489; APO, Fasc. 5, vol. 2, 6o2-6o3, 903-903; APO, Fasc. 5, vol. 3, 13971398, 1403-1404.

115 Quadro Elementar, XIII, 124.

116 APO, Fasc. 5, vol. 2, 512-513. Pereira, História da Administração da Justiça, vol. 1, 120.

117 See Faria (Chapter 4) in this volume.

118 APO, Fasc. 5, vol. 3, 1429-1431; APO, Fasc. 5, vol. 2, 903-904. Pereira, História da Administração da Justiça, vol. 1, 125 . 
and resolve all cases among the newly converted. When this official was not present, these functions were handed over to the captains of the forts, as was the case in the territories of Salcete and Bardez. ${ }^{119}$

Almost 500 forais were rewritten in the Portuguese kingdom between the last decades of the 15th century and the first decades of the 16th. The aim of this administrative reform was to map the tax revenue that the Portuguese municipalities had to pay to the king. While this process was still taking place in the kingdom, a similar one started in Goa, ending with the compilation of the Foral in 1526 . As mentioned above, this document was simultaneously similar and different from the Portuguese ones: it had a first part (today missing) about the taxes to be paid to the king and a second part compiling a selection of local uses and customs, which recovered a practice that had already taken place in the kingdom in the medieval period. Since there are no other documents comparable to the Foral in other parts of the Portuguese empire, it can reasonably be said that the Foral was a singular document and a testimony to the particular relationship established by the Portuguese Crown with the Goan territories and people in the first decades of the 16th century, during the period of the 'apprenticeship of empire'. At this time, what was the role of Goan village normativities in the making of the Portuguese imperial order? How can we assess these normativities through the Foral, the earliest imperial document to map some of them? How did it constitute and construct the normativities taken by the Portuguese imperial agents (and, later, scholars) as the village normativities? Furthermore, given that it was a document produced for a non-Christian Goa, what was its relevance in a Christianized Goa?

Let us return to the idea that the Foral is only a "small inroad" to assessing the village's normativities. The pages above have demonstrated that what we today call the Foral was only the second part of a document that included, in the first part, the taxes that the villages of Goa had to pay to the Portuguese Crown in 1526. Even if later documents compiled these taxes, the first part of the Foral would undoubtedly be useful for connecting the fiscal duties of the villages with the uses and customs selected to be included in the second part.

119 APO, Fasc. 5, vol. 3, 974-975. See also the documentation published by Abranches Garcia (Garcia, Arquivo da Relação de Goa) and Pereira, História da Administração da Justiça, vol. 2, 311-312. 
Nevertheless, this link is missing and with it so are some of the meanings of the Foral.

This aspect related to the production of the Foral converges, in a very evident way, with the notion of its selective nature, stressing the idea that the Foral has to be used very cautiously when studying the normativities operating in the Goan villages. The selective nature of the second part of the Foral was the result of several variables. On the one hand, the Foral was the outcome of a continuous process by the Portuguese imperial agents of becoming acquainted with the land of Goa. As mentioned above, the thānedārs of Goa collected much of the information included in the Foral since 1515. This means that the contents of the Foral are also the result of their processes of getting to know the land, which involved Portuguese agents and local informants. Little is known, however, about these previous processes. In addition to the filters and layers of information already identified in the process of production of the Foral, its contents were submitted to other various other filters and layers about which we know almost nothing. Moreover, as the Sentença of 1534 states, the work of Mexia was probably done "in a rush". Not knowing how much time Mexia did dedicate to the material production of the Foral, it is clear that this was mainly a pragmatic document that selected as much as it excluded.

Unlike Mexia, other officers were more cautious and "professional" when gathering information, thus, the diversity of attitudes is evident, particularly considering the imperial agents' local interlocutors. Though we know almost nothing about who the interlocutors of the thānedārs were, the same applies to the gaunkars of the villages of Goa that were convoked by Mexia. Who were these gaunkars? Who did the gaunkars involved in the production of the Foral truly represent? Knowing that, in 1541, only the gaunkars of 15 villages contributed to the creation of a new Foral, one can hypothesize that the same happened during the creation of the original Foral. We know nothing, either, about the castes of the gaunkars involved in the process, even if we do know that the scribes of the villages were Brahman. Nevertheless, we do know that the villages of Tiswadi had gaunkars belonging to different castes: Brahmans dominated some of them, Charodos (who considered themselves of Kshatriya descent) and Sudras dominated others. Some villages had mixed gaunkaris, too. Did the gaunkars involved in the production of the Foral belong to different castes? If so, did their different ways of living shape the contents of the Foral? These and many other questions remain open.

The little knowledge we do have about the production of this document is telling about its status as a historical source, particularly considering all the missing information about its contexts of production. It is also telling, however, about the relevance it acquired after its production. The diversity of 
voices involved in the Foral were somehow frozen and homogenized since the moment of its writing. Yet, this very process meant that some village normativities did play a role in contributing to the Portuguese imperial order. It is true that the mere act of writing down the norms agreed between some local informants and some Portuguese agents meant an interference in the local order. However, it also contributed to establishing specific rules, certain procedures, and, overall, the power of the local elites that had been recognized by the Portuguese as their privileged informants. Is it possible that these local informants had invited royal interference in order to reinforce their local power? If so, this would have meant that the gap between the contents of the Foral and the people it applied to is even more meaningful than what scholarship has assumed until now. In that sense, the Foral became, ironically (but also understandably), the 'written constitution' of the Goan villages that simultaneously satisfied Portuguese power and the local elites.

However, this equilibrium changed dramatically with the Christianization of the Goan villages, making it clear that the Portuguese Crown had two different approaches in their relationship with the local populations during the 16th century. The first, which roughly corresponds to the government of King D. Manuel I and the first decade of the government of King D. João III, was more secular, less concerned with religious issues, and more 'pluralistic'. For example, the Foral accepted the existence of bigamy and polygamy among the Goan people, even if these practices contradicted Portuguese rule and Christian values. Moreover, the Foral is almost absent in what concerns religious matters in general, accepting the Hindu organization of the local order. In that sense, the Foral was still an expression of the legal pluralism that characterized the Portuguese political order as well as the idea that the laws that organized each political community should be respected.

The second approach, more religious and less open to cultural differences, started to become visible in the decade of 1530 , shortly after the production of the Foral. It meant the destruction of the religious and ritual life in the villages and the Christianization of the local populations. Due to the equivalence between generatio and regeneratio, converted Goans would be fully covered by Portuguese law from the moment of conversion onwards. This meant that the clauses of the Foral, which contradicted Portuguese law and Christian values, were applied less and less. In addition, from that moment onwards, there was an expansion of the law of the kingdom and the contraction of the local customs, namely those included in the Foral. Predictably, since then, Christian judicial officers started to solve minor conflicts and crimes either between the converted or between the converted and non-converted. 
If these policies already limited the applicability of the Foral in the 16th century, by 1720 the Foral faced an entirely new local reality when the Portuguese law applied to 92.2 per cent of the Goan population. ${ }^{120}$ This situation was in deep contrast with the moment of its production. At that time, most of the population of Goa was composed by non-Christians and was supposed to be governed by the Foral. This change in the demography of Goa meant that the norms included in the Foral that only covered the non-Christians applied to increasingly fewer people. Carmo D'Souza was probably right when he wrote that "Portuguese jurisprudence seemed to have prevailed over the indigenous system in the Old Conquests by the seventeenth century". ${ }^{121}$ This 'Lusitanization' of the relationship between the Portuguese administrative and legal order and the village normativities was sealed in a set of rules known as the Regimento of 1735 when the Portuguese Crown made new norms for the government of the villages, which would substitute the ones included in the Foral. This does not imply, however, that this process fully succeeded and that local orders did not continue to operate in parallel with the imperial order. Nevertheless, it witnesses the intentionality of the Portuguese Crown in imposing onto the local normativities what was considered, by then, the 'Portuguese way' of doing things.

Does this mean that the Foral is unreliable in recovering specific dimensions of the normativities that organized the Goan villages? This chapter argues that, despite its shortcomings, the Foral and all it entails is still necessary for assessing some aspects of the local order. The very fact that it voiced the interests and expectations of some (possibly Brahmanical) local elites provides an insight into the local order and its dynamics. A step back in history and a movement in geography are also useful for understanding whether there were links between some of the norms included in the Foral and more general South Indian juridical traditions. Derrett's intuition was probably right: in a complex and contradictory way, the Foral evoked, namely in the clauses concerning inheritance, the Indian classical traditions. However-as this chapter demonstrates-the information about the appropriation of these traditions is almost completely lacking, and further research is needed to verify the existence of linkages between these traditions and the Foral.

In any case, the status eventually attributed to the Foral by 19th-century scholars and local elites was, therefore, a convenient fantasy, projecting on the past a narrative that was different from that of the agents genuinely involved

120 Matos, "O numeramento de Goa de 1720", 321-324.

121 D'Souza, Legal Systems of Goa, vol. 2, 114. 
in the production of the Foral. As mentioned at the beginning of this chapter, these 19th-century readings did contribute to shaping subsequent scholarship by overstating the descriptive power of the Foral and overlooking its constructive nature. By doing this, this scholarship contributed to a particular "vision of community",122 as well as 'invent [ing] a tradition' that has persisted until today in the commonsense of the Goan people. ${ }^{123}$ Furthermore, it gave legitimacy to the idea that legal and administrative pluralism characterized all of the Portuguese imperial experience in Goa, and that the Portuguese imperial order largely preserved the village normativities. As the previous pages have demonstrated, this was predominantly untrue. Even if legal pluralism was characteristic of the first two decades of the Portuguese imperial presence in Goa, and plural normativities coexisted in Goa in different times and modalities. This plurality was of a different nature to what is usually included under the label of legal pluralism.

\section{Acknowledgements}

Previous versions of this essay were presented at the "Norms and Empires Lecture Series" coordinated by Manuel Bastias Saavedra at the Max-Planck Institut für Rechtsgeschichte und Rechtstheorie, Frankfurt; at the "History and Historiography of Brazil Seminar", coordinated by Laura de Mello e Souza in the Université de Sorbonne I, Paris; in the "Reading Seminar" of the Research Group "Empires, Colonialism, and Post-Colonial Societies" of the Instituto de Ciências Sociais da Universidade de Lisboa; and in the II Encontro HispanoLuso de História do Direito, Lisboa. I would like to thank the audience of these seminars for their comments and suggestions. I am also truly indebted to the insightful and critical reading and comments by Manuel Bastias Saavedra and Sumit Guha, as well as the anonymous reviewers of this text. Finally, I would like to thank Genevieve Beech for the English revision, which much improved the text. This is part of the project Legal Pluralism in the Portuguese Empire (18th-2oth centuries), PTDC/DIR-OUT/30873/2017 coordinated by Cristina Nogueira da Silva in CEDIS-UNL and funded by the Fundação para a Ciência e Tecnologia. All translations from documents and scholarship in Portuguese or languages other than English are mine.

\footnotetext{
122 Kroppenberg and Linder, "Coding the Nation. Codification History from a (Post)Global Perspective", 67-99.

On that, see the article of Fernandes, "Invoking the Ghost of Mexia", 9-25.
} 


\section{Abbreviations}

APO Archivo Portuguez-Oriental

HAG Historical Archives of Goa

IAN/TT Instituto Nacional de Arquivos/Torre do Tombo

AHU Arquivo Histórico Ultramarino

Fasc. Fascículo

OrdMan Ordenações Manuelinas

\section{Bibliography}

\section{Manuscripts}

Arquivo Histórico Ultramarino (AHU), Lisbon, India: Cx 6, no. 29.

Historical Archives of Goa (HAG), Assentos da Relação de Goa, no. 8779, no. 79

Instituto Nacional de Arquivos / Torre do Tombo (IAN/TT), Lisbon, Armário Jesuítico, Mss. 89, no. 19.

\section{Printed Sources}

Archivo Portuguez Oriental, ed. by Joaquim Heliodoro da Cunha Rivara, 6 vols., repr. in Delhi 1992.

Barros, João de, Décadas da Ásia, 3 vols., Lisboa 1988-1994.

Boemus, Johannes, Omnium Gentium Mores, Leges et Ritus ex multis clarissimis rerum scriptoribus, sn., sl., 1520.

Dāya-Bhāga and Mitākșarā. Two Treatises on the Hindu Law of Inheritance, trans. H. T. Colebrooke, repr. in Delhi 1984.

Documentação Remetida da Índia ou Livros das Monções, ed. by Raymundo António de Bulhão Pato, 10 vols., Lisboa 1880-1982.

Documentação para a História do Padroado Português do Oriente:Índia, ed. by António da Silva Rego, 12 vols., Lisboa 1947-1958.

Epigraphica Indica, vol. 7, Delhi 1980.

Foral dos usos e costumes dos Gancares e Lavradores da Itha de Goa e outras annexas a ella, in Rivara, Joaquim Heliodoro da Cunha, in Archivo Portuguez Oriental, Fasc. 5, vol. 1, Delhi 1992.

Ordenações Manuelinas, 5 vols., Lisboa 1984.

Paes, Domingos, Chronica dos Reys de Bisnaga: manuscrito inedito do século XVI, ed. David Lopes, Lisboa 1887.

Paes, Francisco, Tombo das Ithas de Goa e das Terras de Salcete e Bardês, ed. P.P. Pissurlencar, Goa 1952. 
Pires, Tomé, Summa Oriental, in The Suma Oriental of Tomé Pires (...) and the Book of Francisco Rodrigues (...), trans. Armando Cortesão, London 1944.

Sama, Krsnadasa, Koṃkaṇi Rāmāyaṇa: kristī dharmaprasārakāṃcyā hātāṃtalyāna dhvanyātmaka romīkaraṇa, ed. Olivinho Gomes, Goa 1996.

The Book of Duarte Barbosa, 2 vols., ed. by Mansel Longworth Dames, London 1918. Wicki, Joseph, S.J., Documenta Indica (DI), 12 vols., Rome 1948-1972.

\section{Literature}

Agüero, Alejandro, "Local law and Localisation of law. Hispanic Legal Tradition and Colonial Culture (16th-18th Centuries)", in Meccarelli, Massimo and Maria Julia Solla Sastre (eds.), Spatial and Temporal Dimensions for Legal History. Research Experiences and Itineraries, Global Perspectives on Legal History, Frankfurt am Main 2016, 101-130.

Alam, Muzzafar and Sanjay Subrahmanyam, "The making of a munshī", in Sheldon Pollock (ed.), Forms of Knowledge in early modern Asia. Explorations in the Intellectual History of India and Tibet 1500-1800, Durham and London 2011, 185-209.

Axelroad, Paul e Michelle Fuerch, "Portuguese Orientalism and the making of the Village Communities in Goa", in Ethnohistory 45:3 (Summer 1998): 439-476.

Alencastro, Luiz Filipe, "The Apprenticeship of Colonization", in Patrick Manning, Slave Trades, 1500-1800, Globalisation of Forced Labour, Aldershot/Burlington USA/ Singapore/Sydney, 1996, 83-106.

Axelroad, Paul, "Living on the edge: The village and the state on the Goa-Maratha frontier", in The Indian Economic and Social History Review (Dec. 2008): 553-580.

Baden-Powell, B. H., "The Villages of Goa in the Early Sixteenth Century", in Journal of The Royal Asiatic Society 32: 2 (1900): 261-291.

Benton, Lauren, Law and Colonial Cultures: Legal Regimes in World History, 1400-1900, Cambridge 2002.

Bhattacharyya-Panda, Nandini, Appropriation and Invention of Tradition: The East India Company and Hindu Law in Early Colonial Bengal, Delhi 2008.

Cohn, Bernard S., Colonialism and its forms of knowledge: The making of British India, Princeton, 1996.

Coelho, Maria Helena da Cruz, “O Poder Concelhio em tempos medievais - o 'deve’ e 'haver' historiográfico”, in Revista da Faculdade de Letras — HISTÓRIA, II I Série, vol. 7 (2006): 19-34.

Coulson, Noel J., A History of Islamic Law, 2nd ed., New Brunswick and London 2011.

Couto, Dejanirah, "The Role of Interpreters, or Linguas, in the Portuguese Empire During the 16th Century", E-Journal of Portuguese History 1:2 (Winter 2003): 1-10.

D’Souza, Carmo, Legal Systems in Goa (1510-1986), Panaji 2012.

Dasgupta, Sashi Bushan, Obscure Religious Cults as Background of Bengali Literature, Calcutta 1946. 
Davis, Donald R., "Dharma, Maryāda and Law in Early British Malabar. Remarks on words for 'Law' in the Tellicherry records", in Studien zur Indologie und Iranistik 23 (2002): 51-70.

Davis, Donald R., Jr., and David Brick, "Social and Literary History of Dharmaśãstra Commentaries and Legal Digests", in Patrick Olivelle and Donald Richard Davis, Jr. (eds.), Hindu Law: A New History of Dharmaśãstra, Oxford 2018, 30-45.

Davis, Donald Richard, "Introduction", in Patrick Olivelle and Donald Richard Davis, Jr. (eds.), Hindu Law: A New History of Dharmaśãstra, Oxford 2018, 1-11.

Davis, Donald Richard, Jr., The boundaries of Hindu Law: tradition, politics and custom in Medieval Kerala, Torino 2004.

Derrett, John Duncan Martin, Essays in Classical and Modern Hindu Law. Dharmaśãstra and Related Ideas, Leiden 1976.

Derrett, John Duncan Martin, "Law and social order before the Muhammadan conquests," in Journal of the Economic and Social History of the Orient 7:3 (1964): 73-120.

Derrett, John Duncan Martin, "Hindu law in Goa: A contact between Natural, Roman and Hindu Laws", in Derrett, John Duncan Martin, Essays in Classical and Modern Hindu Law: Consequences of the Intellectual Exchange with the Foreign Powers, Leiden 1977, 131-165.

Derrett, John Duncan Martin, Essays in Classical and Modern Hindu Law: Consequences of the Intellectual Exchange with the Foreign Powers, Brill 1977.

Deshpande, Prachi, "Scripting the Cultural History of Language: Modi in the Colonial Archive", in Chatterjee, Partha, Tapati Guha-Takurti and Bodhisattva Karr (eds.), New Cultural Histories of India: Materiality and Practices, Delhi 2014, 62-86.

Dias, Remy, A Socio-Economic History of Goa with Special reference to the Communidade System, 1750-1910 (PhD Thesis), Goa 2004.

Duve, Thomas (ed.), Entanglements in Legal History: Conceptual Approaches, Global Perspectives on Legal History, Frankfurt am Main 2014.

Duve, Thomas, "European Legal History - Concepts, Methods, Challenges”, in Duve, Thomas (ed.), Entanglements in Legal History: Conceptual Approaches, Global Perspectives on Legal History, Frankfurt am Main 2014, 29-66.

Fernandes, Jason Keith, "Invoking the Ghost of Mexia: State and Community in Post-Colonial Goa”, in Ler História $5^{8}$ (2010): 9-25.

Fischer, Elaine M., Hindu Pluralism. Religion and the Public Sphere in the Early Modern South India, Oakland 2017.

Flores, Jorge, "Le «língua» cosmopolite. Le monde social des interprètes hindous de Goa au XVIle siècle," in Lefèvre, Corinne, Ines G. Županov and Jorge Flores (eds.), Cosmopolitismes en Asie du Sud sources, itinéraires, langues, XVIe-XVIIIe siècle, in Purushártha 33 (2015) :225-250.

Fukazawa, Hiroshi, "A Study of the Local Administration of Adilshahi Sultanate (A.D. 1489-1686)", in Hitotsubashi Journal of Economics 3:2 (1963): 37-66. 
Fukazawa, Hiroshi, "Rural servants in 18th century Maharastra. Demiurgic or Jajmani System?", in HitotsubashiJournal of Economics 12:2 (1972): 14-40.

Galindo, George Rodrigo Bandeira, "Legal transplants between time and space", in Duve, Thomas (ed.), Entanglements in Legal History: Conceptual Approaches, Global Perspectives on Legal History, Frankfurt am Main 2014, 129-148.

Gomes, Olivinho, Old Konkani language and literature: the Portuguese role: Chandor, Goa 1999 .

Gordon, Stuart N., Marathas, marauders, and state formation in eighteenth century India, London 1994.

Guerra, François-Xavier, "L'État et les Communautés: Comment Inventer un Empire. Introduction", in Serge Gruzinski and Nathan Wachtel (dirs.), Le Nouveau Monde. Mondes Nouveaux. L'Expérience Américaine, Paris 1992, 351-364.

Guha, Sumit, "The Political Economy of Village Life", in Guha, Sumit, Beyond Caste, Identity and Power in South Asia. Past and Present, Leiden-Boston 2013, 83-116.

Gune, Vithal Trimbak, The Judicial System of the Marathas, Poona 1953.

Hallaq, Wael B., An Introduction to Islamic Law, Cambridge 2009.

Halpérin, Jean-Louis, "Transplants of European Normativity in India and in Japan: a Historical Comparison”, in Rechtsgeschichte - Legal History 22 (2014): 150-157.

Herzog, Tamar, "Colonial law: Early Modern Normativity in Spanish America”, in Tellekamp, Jörg Alejandro (ed.), A Companion to Early Modern Spanish Imperial and Political Thought, Leiden-Boston 2020, 105-127.

Hespanha, António Manuel, Como os Juristas viam o mundo, 1550-1750, Direitos, estados, pessoas, coisas, contratos, ações e crimes, Lisboa 2015.

Hespanha, António Manuel, Panorama da História Jurídica de Macau, Macau 2005.

Hespanha, António Manuel, Os Filhos da Terra. Identidades Mestiças nos confins da expansão portuguesa, Lisboa 2019.

Inden, Ronald, Imagining India, Oxford 1990.

Jaffe, James A., "The languages of petitioning in early colonial India", in Social Science History 43 (2019): 581-597.

Jois, Mandagadde Rama, Legal and Constitutional History of India: Ancient, Judicial and Constitutional System, Delhi 2004.

Kane, Pandurang Vaman, History of the Dharmaśãstras, vol. 1, Poona 1940.

Kosambi, Damodar Dharmanand, “The Village Community in the 'Old Conquests' of Goa", Journal of the University of Bombay 15, no. 4 (1947): 63-78.

Kroppenberg, Inge and Nikolaus Linder, "Coding the Nation. Codification History from a (Post-)Global Perspective”, in Duve, Thomas (ed.), Entanglements in Legal History: Conceptual Approaches, Global Perspectives on Legal History, Frankfurt am Main 2014, 67-99.

Kulkarni, A. R., "The Indian village with special reference to Medieval Deccan (Maratha county): General presidential address", in Proceedings of the Indian History Congress $5^{2}(1991): 1-42$. 
Kumar, Raj, Essays on Legal Systems in India, Delhi 2003.

Lach, Donald F., Asia in the making of Europe, 3 vols., Chicago 1965-1977.

Lapidus, Ira M., A History of Islamic Societies, Cambridge 2002.

Lariviere, Richard W., "Dharmaśãstra, Custom, 'Real Law', and 'Apocryphal' Smrtis”, in Journal of Indian Philosophy 32:5-6 (2004): 611-627.

Lingat, Robert, Les sources du droit dans le système traditionnel de l'Inde. Paris 1967.

Loureiro, Sara, "Reconstituição da documentação produzida por Afonso de Mexia, escrivão da Câmara e da Fazenda Real de D. Manuel I e D. João III", Cadernos do Arquivo Municipal de Lisboa, $1^{\text {a }}$ série, no. 9 (2007): 1-49.

Madeira-Santos, Catarina, "As Instituições Indígenas no Império Português", in Xavier, Ângela Barreto, Federico Palomo and Roberta Stumpf (coord.), Monarquias Ibéricas em Perspectiva Comparada. Dinâmicas Imperiais e Modelos Administrativos (Séculos XVI-XVIII), Lisbon 2018, 271-302.

Magalhães, Manuel, Pequenos Reis e Grandes Honras Culto, Poder e Estatuto na Índia Ocidental (PhD Thesis), Lisbon 2013.

Matos, Paulo Lopes, "O numeramento de Goa de 1720", in Anais de História de AlémMar, 8 (2007), 241-324.

Mawani, Renisa and Iza Hussin, "The Travels of Law: Indian Ocean Itineraries", in Law and History Review 32:4 (2014): 733-747.

Meccarelli, Massimo and Maria Julia Solla Sastre (eds.), Spatial and Temporal Dimensions for Legal History. Research Experiences and Itineraries, Global Perspectives on Legal History, Frankfurt am Main 2016.

Menski, Werner F., Hindu Law: Beyond Tradition and Modernity, Delhi 2003.

Miranda, Susana Münch, A Administração da Fazenda Real no Estado da Índia (1517-1640) (PhD Thesis), Lisbon 2007.

Miranda, Susana Münch, "The center and the periphery in the administration of the Royal Exchequer of the Estado da Índia (1517-1640), in E-Journal of Portuguese History $7: 2$ (2009): 1-14.

Mitchell, Axel, "The Practice of Hindu Law," in Davis, Donald Ronald Jr. and Javanth K. Krishnan, Hinduism and Law: An Introduction, Cambridge 2010, 58-77.

Mitragotri, V. R., Socio-Cultural History of Goa, From Bhojas to Vijayanagar, Goa 1999.

Moraes, George, The Kadamba Kula: A History of Ancient and Mediaeval Karnataka, Bombay 1931 (repr. Delhi 1990).

O'Hanlon, Rosalind and Christopher Minkowski, "What makes people who they are? Pandit networks and the problems of livelihood in early modern Western India", in India Economic and Social History Review 45:3 (2008): 381-416.

O'Hanlon, Rosalind, Christopher Minkowski and Anand Venkatkrishnan (eds.), Scholar Intellectuals in Early Modern India: Discipline, Sect, Lineage and Community, London 2017.

Oliveira, Luís Filipe, "O Foral de Faro e a Reforma dos Forais", in O Foral de Faro de 1504: Apresentação e Edição, Faro 2017, 9-20. 
Olivelle, Patrick and Donald Richard Davis, (eds.), Hindu Law: A New History of Dharmaśãstra, Oxford 2018.

Olivelle, Patrick, "Social and Literary History of Dharmaśãstra - The Foundational Texts", in Olivelle, Patrick and Donald Richard Davis (eds.), Hindu Law: A New History of Dharmaśãstra, Oxford 2018, 17-29.

Pereira, Carlos Renato Gonçalves, História da Administração da Justiça no Estado da Índia, Lisbon 1964.

Pereira, Rui, Gaunkaris (The old villages associations), Goa 1978.

Pinto, Rochelle, "The Foral in the History of the Communidades de Goa," in Journal of World History 29:2 (2018): 185-212.

Pollock, Sheldon (ed.), Forms of Knowledge in early modern Asia. Explorations in the Intellectual History of India and Tibet 1500-1800, Durham and London 2011.

Pollock, Sheldon, The Language of the Gods in the World of Men. Sanskrit, Culture, and Power in Premodern India, Berkeley/Los Angeles/London 2006.

Priolkar, Anant Kakba, The Goa Inquisition, Bombay 1961.

Rao, Velcheru Narayana, David Shulman and Sanjay Subrahmanyam (eds.), Textures of Time. Writing History in South India 1600-1800, Delhi 2003.

Rao, Velcheru Narayana, David Shulman and Sanjay Subrahmanyam, "A new imperial idiom in the Sixteenth Century. Krishnadevaraya and His Political Theory of Vijayanagara", in Sheldon Pollock (ed.), Forms of Knowledge in early modern Asia. Explorations in the Intellectual History of India and Tibet 1500-1800, London and Durham 2011, 69-111.

Rao, Venkat, Cultures of Memory in South Asia. Orality, Literacy and the Problem of Inheritance, New Delhi/Heidelberg/New York/Dordrecht/London 2014.

Rocher, Ludo, Jimutavahana's Dayabhaga: The Hindu Law of Inheritance in Bengal, New York 2002.

Rocher, Ludo, "Hindu Conceptions of Law", The Hastings Law Journal 29 (1978), 1283-1305.

Rocher, Ludo, "The theory of proof in ancient Hindu Law", in Davis, Donald R. (ed.), Studies in Hindu Law and Darmaśāstra, New York 2012, 39-58.

Rocher, Ludo, Studies in Hindu Law and Dharmaśãstras, Davis, Donald R. (ed.), New York 2012.

Rocher, Ludo, "Inheritance dāyabhāga", in Olivelle, Patrick and Donald Richard Davis, (eds.), Hindu Law: A New History of Dharmaśãstra, Oxford 2018, 164-178.

Shastri, B. S., "Gersoppa's hand in the capture of Goa", in B. S. Shastri, Goa-Kanara Portuguese relations, 1498-1763, Porvorim 2000, 24-36.

Sobral Neto, Margarida, "O foral manuelino de Porto de Mós: processo de elaboração, conteúdo e aplicação", in Revista de História da Sociedade e da Cultura 6 (2006): $155^{-176 .}$

Souza, Teotónio de, Medieval Goa: A Socio-Economic History, Goa 1979. 
Stein, Burton, Vijayanagar, vol. 1.2 of The New Cambridge History of India, Cambridge/ New York/Port Chester/Melbourne/Sydney 1989.

Subrahmanyam, Sanjay, "O romântico, o oriental e o exótico: notas sobre os portugueses em Goa”, in Rosa Maria Perez (ed.), Histórias de Goa, Lisboa 1997, 29-43.

Thomaz, Luis Filipe, "Estrutura política e administrativa do Estado da Índia no século XVI", in Thomaz, Luis Filipe, De Ceuta a Timor, Carnaxide 1994.

Viegas, Valentino, As Políticas Portuguesas na Índia e o Foral de Goa, Lisboa 2005.

Xavier, Ângela Barreto, A Invenção de Goa, Poder Imperial e Conversões Culturais nos séculos XVI e XVII, Lisboa 2008.

Xavier, Ângela Barreto and Županov, Ines G., Catholic Orientalism. Portuguese Empire, Indian Knowledge (16th-18th centuries), Delhi 2015.

Xavier, Ângela Barreto, Federico Palomo and Roberta Stumpf (coord.), Monarquias Ibéricas em Perspectiva Comparada. Dinâmicas Imperiais e Modelos Administrativos (Séculos XVI-XVIII), Lisboa 2018.

Xavier, Filipe Nery, Bosquejo Histórico das Communidades das Aldeias dos Concelhos das Ilhas, Salsete e Bardez, 3 vols., Bastorá 1903-1907.

Xavier, Filipe Nery, Collecção de Bandos, e Outras Differentes Providencias Que Servem de Leis Regulamentares para o Governo Economico e Judicial das Provincias Denominadas das Novas Conquistas, Precedida da Nocao da sua Conquista, 3 vols., Pangim 1840.

Xavier, Filipe Nery, Collecção das Leis Peculiares das Communidades Agricolas das Aldeas dos Concelhos das Ilhas, Salsete e Bardez, Nova Goa 1855-1877. 